\title{
Container volume and shading in Parkia multijuga Benth. propagation in nursery
}

\author{
Luiz Maekawa' (1), Maria de Fatima Barbosa Coelho ${ }^{2, *}$ (i), Oscarlina Lúcia dos Santos Weber ${ }^{2}$ (1) \\ 'Instituto Federal de Educação, Ciência e Tecnologia de Mato Grosso, Campus Juína, Linha J, s/n, CEP 78320-000, Juina, MT, Brasil. \\ 2Universidade Federal de Mato Grosso, Programa de Pós-Graduação em Agricultura Tropical, \\ Av. Fernando Correa da Costa s/n, CEP 78060-900, Cuiabá, MT, Brasil. \\ *Autora para correspondência: coelhomfstrela@gmail.com
}

Recebido em 15.V.2019

Aceito em 10.IV.2020

DOI 10.21826/2446-82312020v75e2020012

\begin{abstract}
Parkia multijuca Benth. is one of the Forest species that occurs in the Amazon region. The aim of the this study was evaluate the development of seedlings of Parkia multijuga in differents shading and container volume in nursery. The experimental design was a randomized block design in $4 \times 4$ subplotplot (4 shadings and 4 containers volumes). The shading was $0,30,50$ and $70 \%$ and containerv olumes $110,180,290$ and $400 \mathrm{~cm}^{3}$. The diameter, root drymass, shootdrymass, total dry mass and the Dickson quality índex of the seedlings increased proportionally with container volume and with the availability of light. The conduction of the seedlings in full sun and container volume $400 \mathrm{~cm}^{3}$ favors the development of $P$. multijuga quality seedlings and $70 \%$ shading should not be used in nurseries to produce $P$. multijuga seedlings.
\end{abstract}

Keywords: IQD, light, native forest seedlings

RESUMO - Volume do recipiente e sombreamento na propagação em viveiro de Parkia multijuga Benth. Parkia multijuca Benth. é uma das espécies florestais que ocorre na região amazônica. O objetivo deste trabalho foi avaliar o desenvolvimento de mudas de $P$. multijuga em diferentes sombreamentos e volumes do recipiente. O delineamento experimental utilizado foi blocos ao acaso em esquema de parcelas subdividida $4 \times 4$ ( 4 sombreamentos e 4 volumes dorecipiente). O sombreamento foi $0,30,50$ e $70 \%$ e os volumes $110,180,290$ e $400 \mathrm{~cm}^{3}$. O diâmetro, a massa seca da raiz, a massa seca da parte aérea, a massa seca total e o índice de qualidade de Dickson das mudas aumentaram proporcionalmente com o volume do recipiente e com a disponibilidade de luz. A condução das mudas a pleno sol e o volume dorecipientede $400 \mathrm{~cm}^{3}$ proporcionaram mudas de qualidade de $P$. multijuga e $70 \%$ de sombreamento não deve ser utilizado em viveiros para produção de mudas de $P$. multijuga.

Palavras-chave: IQD, luz, mudas florestas nativas

\section{INTRODUCTION}

The North West Region of Mato Grosso is one of the last unexplored áreas of the State. It presents a great biological diversity, with fragile ecosystems, little studied and is part of the Arch of Deforestation that concentrates some of the most serious environmental problems, among them, unbridled deforestation (WWF 2012) and illegal logging (Silgueiro et al. 2018).

Parkia multijuca Benth. is one of the Forest species that occurs in Amazon region and it is distributed in the States of Amazonas, Para, Maranhão, Acre, Rondônia and Mato Grosso in áreas of forest in the phytogeographic domain of Amazonia (Oliveira \& Hopkins 2018). The species belongs to the Fabaceae family, the largest trees reach dimensions close to $40 \mathrm{~m}$ in height and $100 \mathrm{~cm}$ of DAP (diameter at breash eight, measured at $1.30 \mathrm{~m}$ from the ground) in adult hood and classified as early secondary (Carvalho 2009). $P$. multijuga can also be used in landscaping, especially in urban arborization and public squares (Lorenzi 2008), besides being important for there covery of degraded áreas of permanente preservation, mainly due to its rapid growth (Carvalho 2009).

Native Forest species such as P. multijuga could be used in agroforestry systems, in there covery of areas and in the composition of commercial plantations, however, there is little scientific information about the production of forest seedlings in theregion, because despite the technological advances, the available information on native forest species is still scarce (Ribeiro et al. 2018).

In the processof nursery seedling production, the substrate and the volume available to the roots are fundamental, because it is in this environment that the planting of the seeds or the rooting of seedlings takes place, occurring the due sustentation to the plants, with the supply of water, nutrients and oxygen to the root system (Ribeiro et al. 2018).

Davide \& Faria (2008) stated that pioneer forest species can usually be produced in smaller containers. Thus, it is interesting to study which container volume is most suitable 
for each species, since the containers with larger volume capacity need more substrate and occupy more space in the nursery, which may contribute to increase the final cost of the seedling.

The different light conditions generally cause morphological and physiological variations in theplant, and the degree of adaptation is dictated by its genetic characteristics in interaction with its environment. The consequences of these light intensity differences are more significant in the growth of the plant than in its quality, especially with respect to dry matter accumulation under natural conditions (Scalon et al. 2003).

The shading of seedlings in the nursery stage is also important and verifying the developmen of plants under controlled conditions with the use of artificial shading with screen allows to verify the tolerance of the species to the amount of light received (Borges et al. 2014). Plant species be have differently in relation to shading. Tabebuia aurea (Manso) Benth. \& Hook. Seedlings were not influenced by the luminosity to which they were submitted (Pinto et al. 2016), whereas, Caesalpinia ferrea Mart. ex. Tul. var. leiostachya Benth. presented better growth rates when kept in na environment with 50\% shading (Lenhard et al. 2013).

Parkia multijuga is a species threatened with extinction and of interest in planting by the producers in the North West of Mato Grosso. The seedlings of this species are expected to develop differently when subjected to light constraints and to increase the container volume. Thus, the present study aims to identify the best combinations of container volume and shading for the development of P. multijuga seedlings in nursery.

\section{MATERIAL AND METHODS}

The study was conducted at the Federal Institute of Education, Science and Technology of Mato Grosso (IFMT), located in the Municipality of Juína, Mato Grosso, at the geographic coordinates $11^{\circ} 26^{\prime} 48.9^{\prime \prime} \mathrm{S}$ and $58^{\circ} 43^{\prime} 22.0^{\prime \prime} \mathrm{W}$, with altitude of $311 \mathrm{~m}$. According to the classification of Köppen and Geiger, the climate of Juína is Aw, tropical with dry season in the winter. The mean temperature in 2016 and 2017 was $24.8^{\circ} \mathrm{C}$ and the mean annual precipitation in the municipality was $1,850 \mathrm{~mm}$ (INMET 2018).

Parkia multijuga pods were collected in Five treeson February 2016 in the municipality of Juína at coordinates $11^{\circ} 22^{\prime} 09.5^{\prime \prime S}$ and $58^{\circ} 45^{\prime} 27.6^{\prime \prime} \mathrm{W}$ and the seeds were placed in plastic bags in the IFMT room under ambient conditions. In October 2016 the seeds were mechanically scarified with scissors of pruning on the opposite side of the radicle location tôo vercome dormancy, immersed in recipient with water for 3 periods of 6 hours, with a 30 minute interval of oxygenation.

These seeds, soaked in water, were transported to suspended germinators filled with sawdust powder substrate and covered with $1 \mathrm{~cm}$ of sawdust for 7-8 days. After this period, the integuments surrounding the seeds were removed manually the seeds were placed in plastic tube containers according to treatment, volumes of commercial substrate Plantmax Florestal ${ }^{\circledR}$.

The experimental design was a randomized complete blockwith $4 \times 4$ subplotplot (4 light conditions and 4 volumes capacities of the containers) with 4 replicates of 20 plants. The light conditions were full sun, 30, 50 and $70 \%$ shading constituted the plots. The subplots were 110 , 180,290 and $400 \mathrm{~cm}^{3}$ container volume.

At 180 days the evaluation of the seedlings was carried out with the measurement of diameter (with caliper at substrate level) and height (with millimeter ruler from base to apical bud), number o fleaves, and determination of the biomass. The plants were washed and dried for 48 hours at a temperature of $65^{\circ} \mathrm{C}$ in air circulation dryingstove, brandSolab, model SL - 102, in the IFMT. The dry mass of shoot and roots were obtained in na electronic digital scale, brandEdutec, model EJ-320 A tothenearest 0,01g.

The data obtained were used to calculate the morphophysiological parameters relation between shoot height and shoot diameter (H/D), relation between shoot height and dry hootmass (H/DSM), ratio between dry shoot mass and dry root mass (DSM/DRM), ratio between dry root ratio and dry shoot mass (DSR/DRM), and Dickson quality index (DQI), which is determined as a function of total dry mass, height $(\mathrm{H})$, diameter (D), dry shoot mass (DSM) and dry root mass (DRM), by means of Equation (Dickson et al. 1960):

$$
\mathrm{DQI}=\frac{\mathrm{TDM}(\mathrm{g})}{\left(\frac{\mathrm{H}(\mathrm{cm})}{\mathrm{D}(\mathrm{cm})}\right)+\left(\frac{\mathrm{DSM}(\mathrm{g})}{\mathrm{DRM}(\mathrm{g})}\right)}
$$

The data were tested for variance analysis assumptions, analyzed, and the means were compared by the Scott Knott testat the 5\% probability level using the SISVAR software (Ferreira 2014).

\section{RESULTS}

The analysis of variance showed that there was a significant difference for the effects isolated light conditions and container volume, but there was no difference for the interaction between these.

\section{Container volume effects}

The diameter of the seedling was larger in the largest container $\left(400 \mathrm{~cm}^{3}\right)$ and the largesth eight and number of leaves occurred in the container volume of $290 \mathrm{~cm}^{3}$ (Tab.1).

Dry root mass, shootmass, and total dry mass of $P$. multijuga increased with increasing container volume, so the largest biomass occurred with $400 \mathrm{~cm}^{3}$ container volume (Tab. 1). 
Table 1. Diameter (D), plant height (PH) and number of leaves (NL), dry root mass (DRM), dry shoot mass (DSM) and total dry mass (TDM) of Parkia multijuga seedlings in different container volume. Juína-MT, 2018

\begin{tabular}{ccccccc}
\hline Container volume $\left(\mathrm{cm}^{3}\right)$ & D $(\mathrm{mm})$ & PH $(\mathrm{cm})$ & LN & DRM $(\mathrm{g})$ & TDM $(\mathrm{g})$ \\
\hline 110 & $8.16 \mathrm{c}$ & $42.59 \mathrm{~b}$ & $3.90 \mathrm{c}$ & $17.05 \mathrm{c}$ & $62.10 \mathrm{~d}$ \\
180 & $8.79 \mathrm{~b}$ & $43.51 \mathrm{~b}$ & $4.08 \mathrm{~b}$ & $19.31 \mathrm{~b}$ & $52.58 \mathrm{c}$ \\
290 & $8.70 \mathrm{~b}$ & $45.68 \mathrm{a}$ & $4.63 \mathrm{a}$ & $20.89 \mathrm{~b}$ & $56.34 \mathrm{~b}$ & $77.24 \mathrm{~b}$ \\
400 & $9.36 \mathrm{a}$ & $41.53 \mathrm{~b}$ & $4.20 \mathrm{~b}$ & $24.03 \mathrm{a}$ & $64.82 \mathrm{a}$ \\
\hline
\end{tabular}

Minor letters equals in the column indicate the means do not differ significantly according to Scott Knott's test at 5\% probability.

The smallest relations hip between height and diameter (H/D) and height and dry shoot mass (H/DSM) occurred with the largest container $\left(400 \mathrm{~cm}^{3}\right)$. There was no difference between the means in the DRM/DSM and DSM/DRM ratios, whilethe QDI was higher in the largest recipient $\left(400 \mathrm{~cm}^{3}\right)$ (Tab. 2).

\section{Shading effects}

The diameter of the plant was inversely proportional to the shading, the high plant height were verified with
$70 \%$ of shading and there was no difference between the mean number of leaves in the light conditions and as the shading of the seedlings increased, the biomass values of root, shoot and total biomass decreased (Tab. 3).

Regarding the H/D, H/DSM and DSM/DRM ratios, $P$. multijuga plants presented higher values in $70 \%$ shading and the lowest averages under full Sun treatment, and inverse behavior, higher values in full Sun were observed for the DRM/DSM and DQI ratios (Tab. 4).

Table 2. Relationship between height and diameter (H/D), height and dry mass (H/DSM), root dry mass and dry shoot mass (DRM/DSM), dry shoot mass and root dry mass (DSM/DRM) and Dickson quality index (QDI) of P. multijuga seedlings under different container volume. Juína-MT, 2018

\begin{tabular}{cccccc}
\hline Container volume $\left(\mathrm{cm}^{3}\right)$ & H/D & H/DSM & DRM/DSM & DSM/DRM & QDI \\
\hline 110 & $5.29 \mathrm{a}$ & $0.98 \mathrm{a}$ & $0.37 \mathrm{a}$ & $2.81 \mathrm{a}$ & $15.18 \mathrm{~b}$ \\
180 & $5.00 \mathrm{a}$ & $0.84 \mathrm{~b}$ & $0.37 \mathrm{a}$ & $2.83 \mathrm{a}$ & $17.88 \mathrm{~b}$ \\
290 & $5.33 \mathrm{a}$ & $0.82 \mathrm{~b}$ & $0.37 \mathrm{a}$ & $2.87 \mathrm{a}$ & $18.10 \mathrm{~b}$ \\
400 & $4.47 \mathrm{~b}$ & $0.64 \mathrm{c}$ & $0.37 \mathrm{a}$ & $2.84 \mathrm{a}$ & $23.17 \mathrm{a}$ \\
\hline
\end{tabular}

Minor letters equals in the column indicate the means do not differ significantly according to Scott Knott's test at 5\% probability.

Table 3. Diameter (D), plant height (PH) and number of leaves (NL), dry root mass (DRM), dry shoot mass (DSM) and total dry mass (TDM) of Parkia multijuga Benth. seedlings in different shading conditions. Juína-MT, 2018

\begin{tabular}{ccccccc}
\hline Shading conditions $(\%)$ & D $(\mathrm{mm})$ & PH $(\mathrm{cm})$ & NL & DRM $(\mathrm{g})$ & DSM $(\mathrm{g})$ & TDM $(\mathrm{g})$ \\
\hline 0 & $9.46 \mathrm{a}$ & $39.09 \mathrm{~d}$ & $4.18 \mathrm{a}$ & $26.32 \mathrm{a}$ & $59.02 \mathrm{a}$ & $85.34 \mathrm{a}$ \\
30 & $8.93 \mathrm{~b}$ & $44.11 \mathrm{c}$ & $4.37 \mathrm{a}$ & $21.15 \mathrm{~b}$ & $56.64 \mathrm{a}$ & $77.79 \mathrm{~b}$ \\
50 & $8.78 \mathrm{~b}$ & $42.44 \mathrm{~b}$ & $4.06 \mathrm{a}$ & $19.54 \mathrm{c}$ & $54.83 \mathrm{a}$ & $74.37 \mathrm{~b}$ \\
70 & $7.85 \mathrm{c}$ & $47.66 \mathrm{a}$ & $4.19 \mathrm{a}$ & $14.27 \mathrm{~d}$ & $48.30 \mathrm{~b}$ & $62.57 \mathrm{c}$ \\
\hline
\end{tabular}

Minor letters equals in the column indicate the means do not differ significantly according to Scott Knott's test at $5 \%$ probability.

Table 4. Relationship between height and diameter (H/D), shoot height and dry mass (H/DSM), root dry mass and dry shoot mass (DRM/DSM), dry shoot mass and root dry mass (DSM/DRM) and Dickson quality index (DQI) of $P$. multijuga Benth. seedlings under different shading conditions. Juína-MT, 2018

\begin{tabular}{cccccc}
\hline Shadding conditions (\%) & H/D & H/DSM & DRM/DSM & DSM/DRM & DQI \\
\hline 0 & $4.14 \mathrm{c}$ & $0.67 \mathrm{c}$ & $0.45 \mathrm{a}$ & $2.29 \mathrm{c}$ & $23.10 \mathrm{a}$ \\
30 & $4.97 \mathrm{~b}$ & $0.79 \mathrm{~b}$ & $0.37 \mathrm{~b}$ & $2.73 \mathrm{~b}$ & $18.73 \mathrm{~b}$ \\
50 & $4.86 \mathrm{~b}$ & $0.78 \mathrm{~b}$ & $0.36 \mathrm{~b}$ & $2.89 \mathrm{~b}$ & $18.46 \mathrm{~b}$ \\
70 & $6.12 \mathrm{a}$ & $1.03 \mathrm{a}$ & $0.29 \mathrm{c}$ & $3.43 \mathrm{a}$ & $14.04 \mathrm{c}$ \\
\hline
\end{tabular}

Minor letters equals in the column indicate the means do not differ significantly according to Scott Knott's test at 5\% probability. 


\section{DISCUSSION}

\section{Container volume effects}

In general, the quality standard of the seedlings has a high correlation with the diameter, generating higher rates of survival and growth in the field (Puértolas et al. 2012), hence the importance of seedlings with larger diameter. Greater substrate volume can mean greater development of the root system and quality seedlings as verified by Melo et al. (2018) in Mimosa caesalpiniifolia Benth. plants produced in 110,180 and $280 \mathrm{~cm}^{3}$ volumes that presented higher quality morphological values in nursery when compared to the seedlings produced in 30 and 55 $\mathrm{cm}^{3}$ volumes. The diameter of Toona ciliata M. Roem. var. australis seedlings had the highest values at $280 \mathrm{~cm}^{3}$ substrate volume and the lowest values at $110 \mathrm{~cm}^{3}$ substrate volume (Lisboa et al. 2012). Schizolobium parahyba (Vell.) S. F. Blake. seedlings in the nursery had the diameter increased with the largest substrate volume $\left(300 \mathrm{~cm}^{3}\right)$ (Figueiró et al. 2017).

Hence the importance of larger container volume to obtain larger diameter seedlings as observed in the present study. In relation to the effect of container volume at number of leaves, there agree with Viana et al. (2008) that studying the production of seedlings of Bauhinia forficata Link. And verified that the larger container volume positively influenced the number of leaves.

Studies aiming to evaluate the influence of container volume on the growth of forest seedlings have shown that the use of larger containers form larger seedlings and considered of better morphological quality (Antoniazzi et al. 2013, Baldin et al. 2015, Melo et al. 2018). This fact was also verified in the present study in which the largest biomasses (DSM, DRM and DMT) occurred proportionally with the increase of the container volume (Tab. 2), possibly because it provided higher nutrient availability. Biomass production hás been considere done of the Best parameters to characterize the quality of seedlings, but it hás the disadvantage that its determination in many nurseries is not feasible, mainly because it involves the complete destruction of seedlings and the use of greenhouses (Eloy et al. 2013).

The height/diameter ratio expresses the idea of robustness of the plant (low value) in contrast to the thin aspect (high value), verified when cultivated at high densities, due to estiolation. Thus, it expresses the growth balance of the seedling, considering that smaller relationships indicate greater capacity of the seedlings to survive and settle in the field (Gomes \& Paiva 2012). According to Rossa et al. (2013), based on the literature, seedlings with $\mathrm{H} / \mathrm{D}$ ratio lowest than 10 are considered of excellent quality, which would minimize mortality in the Field after planting. Gasparin et al. (2014) verified H/D of 3.22 in seedlings of Cabralea canjerana (Vell.) Mart. in the $280 \mathrm{~cm}^{3}$ tube, lower than that observed in this study, due to the lower growth of the shoot. However, this relations should not be considered in isolation, and all morphophysiological parameters must be considered in order to choose the conditions that provide quality changes.

The DSM/DRM and DRM/DSM relations outline how the distribution of assimilate between the parts of the plant (partthat transpiring $\mathrm{x}$ partthat absorbs water). The absence of significant difference between DSM/DRM and DRM/ DSM ratios indicates that the seedlings presented the same pattern of dry matter distribution between the two organs, regard less of the container volume.

Gasparin et al. (2014) did not find difference in the DQI means in Cabralea canjerana (Vell.) Mart. seedlings in tubes of 100 and $280 \mathrm{~cm}^{3}$, while Gonzaga et al. (2016) verifiedin Hymenaea courbaril L. seedlings, DQI of 0.44 in $110 \mathrm{~cm}^{3}$ tubes and 0.76 in plastic bag. The mean values of DQI in P. multijuga seedlings ranged from 15,18to 23.17 (Tab. 3) and the higest value were in largest container volume $\left(400 \mathrm{~cm}^{3}\right)$. The root restriction influenced the total production and thedistribution of the drybiomass, consequently, influenced reduction of the DQI of the seedlings produced in thetreatments with smaller substrate volume. There fore well above the minimum valueof 0.2 established in studies for quality seedlings (Gomes \& Paiva 2012), possibly because of the great development of the seedling found at 180 days of nursery.

\section{Shading effects}

Differently that observed in the present study, Dalbergia nigra (Vell.) Allemão ex. Benth. seedlings had greater diameter in treatments with shading of 50, 70 and $84 \%$ and the species hás characteristics of shadow tolerance and more advanced stages of succession, approaching from late secondary species to climax (Pacheco et al. 2013). However, P. multijuga is a species classified in the initial secondary succession stadium (Carvalho 2009) and possibly requires greater light at the beginning of development in nursery as observed in the presente study.

The result of higher height in treatments with shading is similar to that found in Dalbergia nigra (Vell.) Allemão ex. Benth. seedlings that was highest increase in height, in the treatments with 70 and $84 \%$ of shading, and height was reduced when the seedlings were cultivated under low levels of shading (Pacheco et al. 2013). In relation to the characteristics such as diameter and height of the plant, it is recommended that a seedling considered of quality should have a height between 20 and $35 \mathrm{~cm}$ and a diameter between 3 and $10 \mathrm{~mm}$ (Gomes \& Paiva 2012). In the present study this diameter condition was satisfied in all treatments, but the seedling height values were over $39 \mathrm{~cm}$ (Tab. 4).

There was positive effect of light on the number of leaves of Caesalpinia ferrea Mart. ex Tul. (Lima et al. 2008) and on the other hand, Azevedo et al. (2010) and Reis et al.(2016) verified that the highest number of leaves occurred in the condition of greater shading. This shows that plants of diferente species can present adjustments to 
light availability as observed in the present study where there was no difference in leaf number.

Freitas et al. (2012) observed higher dry mass in Sclerolobium paniculatum Vogel. seedlings in full sun. According to Pacheco et al. (2013) Chorisia speciosa A. St.-Hil. seedlings, there was a significant increase in full Sun treatments $(0 \%)$ and shade treatments $(20$ and $50 \%$ ). This species, according to their searchers, had characteristics of heliophytes species in the initial stages of succession, approaching Pioneer plants to early secondary, such as P. multijuga.

The shading of the seedlings also influenced the relations between shoo theight and dry mass (H/DSM), with values increasing proportionally with greater light restriction, corroborating with the results obtained by De Marco et al. (2014) in Toonaciliata M. Roem. var. australis (F. Muell.) Bahadur), Reis et al. (2015) with Dilodendron bipinnatum Radkl. and Reis et al. (2016) in Copaifera langsdorfffii Desf. The lower values of the H/D and H/ DSM ratios provide greater seedling robustness and better survival capacity after planting (Dutra et al. 2013). Thus, in this studytheseedlingsdeveloped in full sun are better (Tab.4). Increased exposure to photo synthetic radiation increases the assimilate partition to the root system by decreasing the ratio values. The reduction of the root weight under shading is due to the water restriction of the seedlings in full sun, which induces the accumulation of dry mass in the root system, to the detriment of the accumulation of assimilates in the aerial part.

The quality index of Dickson is a important indicator of the quality of the seedlings and the higher the value of this index, the more vigorous Will be the plant because in its calculation are considered the robustness and the balance of the biomass distribution in the plant (Gomes \& Paiva 2012). Thus, the Best treatments were those with the great estavailability of light, as they provided the highest DQI (Table 4). There is a need to complement research at the Field level so that planting of quality seedlings can be indicated, with a high rate of survival and growth.

The conduction of the seedlings in full sun and container volume $400 \mathrm{~cm}^{3}$ favors the development of $P$. multijuga quality seedlings and $70 \%$ shading should not be used in nurseries to produce $P$. multijuga seedlings.

\section{REFERENCES}

Antoniazzi, A. P., Binotto, B., Neumann, G. M., Sausen, T. L. \& Budke, J. C. 2013. Eficiência de recipientes no desenvolvimento de mudas de Cedrela fissilis Vell. (Meliaceae). Revista Brasileira de Biociencias 11:313-317.

Azevedo, I. M. G., Alencar, R. M., Barbosa, A. P. \& Almeida, N. O. 2010. Estudo do crescimento e qualidade de mudas de marupá (Simarouba amara Aubl.) em viveiro. Acta Amazônica 40:157-164.

Baldin, T., Conte, B., Denardi, L., Moraes, R. \& Saldanha, C. W. 2015. Crescimento de mudas de angico-vermelho em diferentes volumes de substratos. Pesquisa Florestal Brasileira 35:129-133.

Borges, V. P., Costa, M. A. P. C. \& Ribas, R. F. 2014. Emergência e crescimento inicial de Tabebuia heptaphylla (Vell.) Toledo em ambientes contrastantes de luz. Revista Árvore 38:523-531.
Carvalho, P. E. R. 2009. Faveira-benguê (Parkia multijuga). Comunicado Técnico, 227 Embrapa Florestas. Colombo. 6p.

Davide, A. C. \& Faria, J. M. R. 2008. Viveiros florestais. In: Davide, A. C. \& Silva, E. A. A. Produção de sementes e mudas de espécies florestais. Universidade Federal de Lavras. Lavras. p.83-124.

De Marco, R., Conte, B., Perrando, E. R., Fortes, F. O., Somavilla, L. \& Burgin, M. B. 2014. Efeito de telas de sombreamento no crescimento e proteção de mudas de Toonaciliata sob baixas temperaturas. Floresta 44:607-616.

Dickson, A., Leaf, A. L. \& Hosner, J. F. 1960. Quality appraisal of whit espruce and white pine seedling stock in nurseries. Forest Chronicles 36:10-13

Dutra, T. R., Massad, M. D., Sarmento, M. F. Q. \& Oliveira, J. C. 2013. Substratos alternativos e métodos de quebra de dormência para produção de mudas de canafístula. Revista Ceres 60:72- 78.

Eloy, E., Caron, B. O., Schmidt, D., Behling, A., Schwers, L. \& Elli, E. F. 2013. Avaliação da qualidade de mudas de Eucalyptus grandis utilizando parâmetros morfológicos. Floresta 43:373-384.

Ferreira, D. F. Sisvar: a Guide for its Bootstrap procedures in multiplecomparisons. 2014. Ciência e Agrotecnologia 38:109-112.

Figueiró, C. G., Macedo F. F., Fialho L. F., Silva C. M. S. \& Cândido W. L. 2017. Efeito do recipiente e do método de superação de dormência no crescimento de mudas de Schizolobium parahyba (Vell.) S. F. Blake. Enciclopédia Biosfera 14:259-266.

Freitas, G. O., Vaz-De-Melo, A., Pereira, M. A. B., Andrade, C. A. O., Lucena, G. N. \& Silva, R. R. 2012. Influência do sombreamento na qualidade de mudas de Sclerolobium paniculatum Vogel para recuperação de área degradada. Journal of Biotechnology and Biodiversity 3:5-12.

Gasparin, E., Avila, A. L., Araujo, M. M., Cargnelutti Filho, A., Dorneles, D. U. \& Foltz, D. R. B. 2014. Influência do substrato e do volume de recipiente na qualidade das mudas de Cabralea canjerana (Vell.) Mart. em viveiro e no campo. Ciência Florestal 24:553-563.

Gomes, J. M. \& Paiva, H. 2012.Viveiros florestais (propagação sexuada). Universidade Federal de Viçosa. Viçosa. 116 p.

Gonzaga, L. M.; Silva, S. S., Campos, S. A., Ferreira, R. P., Campos, A. N. R. \& Cunha, A. C. M. C. 2016. Recipientes e substratos para a produção de mudas de jatobá (Hymenaea courbaril L.). Revista Brasileira de Agropecuária Sustentável 6:64-73.

Instituto Nacional de Meteorologia - INMET $9^{\circ}$ Distrito de Meteorologia, A920 - Juína, MT, 2018. Consulta Genérica: 09/03/2018. Planilha. 2018.

Lenhard, N. R., Paiva Neto, V. B., Scalon, S. P. Q. \& Alvarenga, A. A. 2013. Crescimento de mudas de pau-ferro sob diferentes níveis de sombreamento. Pesquisa Agropecuária Tropical 4:178-186.

Lima, J. D., Silva, B. M. S., Moraes, W. S., Dantas, V. A. V. \& Almeida, C. A. 2008. Efeitos da luminosidade no crescimento de mudas de Caesalpinia ferrea Mart. ExTul. (Leguminosae, Caesalpinoideae). Acta Amazônica 38:5-10.

Lisboa, A. C., Santos, P. S., Oliveira Neto, S. N. O., Castro, D. N. \& Abreu, A. H. M. 2012. Efeito do volume de tubetes na produção de mudas de Calophyllum brasiliense e Toonaciliata. Revista Árvore 36:603-609.

Lorenzi, H. 2008. Árvores brasileiras: manual de identificação e cultivo de plantas arbóreas nativas do Brasil. Instituto Plantarum de Estudos da Flora Ltda. Nova Odessa. 384 p.

Melo, L. A., Abreu, A. H. M., Leles, P.S.S.\& Oliveira, R.R. 2018. Qualidade e crescimento inicial de mudas de Mimosa caesalpiniifolia Benth. produzidas em diferentes volumes de recipientes. Ciência Florestal 28:47-55.

Oliveira, L. C. \& Hopkins, M. Parkia in Flora do Brasil 2020 em construção. Jardim Botânico do Rio de Janeiro. 2018. Disponível em: http://reflora.jbrj.gov.br/reflora/floradobrasil/FB23108 11 Jun. 2018) Acessado em 25.09. 2018.

Pacheco, F. V., Pereira, C. R., Silva, R. L. \& Alvarenga, I. C. A. 2013. Crescimento inicial de Dalbergia nigra (Vell.) Allemão ex. Benth. (Fabaceae) e Chorisia speciosa A. St.-Hil (Malvaceae) sob diferentes níveis de sombreamento. Revista Árvore 37:945-953.

Pinto, J. R. S., Dombroski, J. L. D., Freitas, R. M. O., Souza, G. O. \& Santos Junior, J. H. 2016. Crescimento e índices fisiológicos de 
Tabebuia aurea, sob sombreamento no semiárido. Floresta 46:465472.

Puértolas, J., Jacobs, D. F., Benito, L. F. \& Peñuelas, J. L. 2012. Costbenefit analysis of different container capacities and fertilization regimes in Pinus stock-typeproduction for Forest restoration in dry Mediterranean areas. Ecological Engineering 44:210-215.

Reis, S. M, Marimon-Júnior, B. H., Morandi, P. S., Santos, C. O., Oliveira, B. \& Marimon, B.S. 2016. Desenvolvimento inicial e qualidade de mudas de (Copaifera langsdorfffii Desf). sob diferentes níveis de sombreamento. Ciência Florestal 26:11-20.

Reis, S. M., Morandi, P. S., Oliveira, B., Oliveira, E. A. O., Valadão, M. B. X., Marimon, B. S. \& Marinon-Junior, B. H. 2015. Influência do sombreamento no desenvolvimento inicial e eficiência no uso de nutrientes de Dilodendron bipinnatum Radkl. (Sapindaceae). Scientiae Forestalis 43:581-590.

Ribeiro, R. R., Brun, F. G. K. \& José, E. 2018. Desenvolvimento e nutrição de mudas de acácia-negra (Acacia mearnsii de Wild. De Wild.) em substratos a base de cama de aviário. Revista de Ciências Agroveterinárias 17:36-44.
Rossa, U. B., Angelo, A. C., Nogueira, A. C., Bognola, I. A., Pomianoski, D.J. W., Soares, P.R.C. \& Barros, L.T.S. 2013. Fertilização de liberação lenta no crescimento de mudas de paricá em viveiro. Pesquisa Florestal Brasileira 33:227-234.

Scalon, S. P. Q., Mussury, R. M., Rigoni, M. R. \& Scalon Filho, H. 2003. Crescimento inicial de mudas de Bombacopsis glabra (Pasq.) A. Robyns sob condições de sombreamento. Revista Árvore 27:753-758,

Silgueiro, V., Vadiones, A. P., Cardoso, B. D. \&Thuault, A. 2018. Mapeamento da ilegalidade na exploração madeireira em Mato Grosso entre agosto de 2013 e julho de 2016. Boletim Transparência Florestal do Instituto Centro Vida 9:1-12.

Viana, J. S., Gonçalves, E. P., Andrade, L. A., Oliveira, L. S. B. \& Silva, E. O. 2008. Crescimento de mudas de Bauhinia forficata Link. em diferentes tamanhos de recipientes. Floresta 38:663-671.

World Wide Fund for Nature - WWF. Desenvolvimento Sustentável no Noroeste de Mato Grosso. Comunidade/Sustentabilidade. Projeto BR 2012. WWF - Brasil. Brasília, 2011. 102p. Disponível em: https:// www.wwf.org.br/?31508/Desenvolvimento-Sustentavel-no-noroestedo-Mato-Grosso). Acessado em 12.05.2019 